Sains Malaysiana 50(4)(2021): 1199-1209

http://doi.org/10.17576/jsm-2021-5005-01

\title{
The Diversity of Lichens along Elevational Gradients in the Tropical Montane Forest of Selangor, Malaysia
}

(Kepelbagaian Liken sepanjang Kecerunan Ketinggian di Hutan Gunung Tropika, Selangor, Malaysia)

\author{
AZLAN ABAS* \& LAILY DIN
}

ABSTRACT

This study aims to explore how lichen diversity, composition, and distribution vary with altitude, and environmental factors (temperature and relative humidity). The study was conducted in the forest of Gunung Bunga Buah, Selangor at five sites (different altitudes). Forty-four lichen species were identified. Their diversity, composition, and distribution correlated significantly with the altitude and environmental factors, increasing diversity at higher altitudes. Graphidaceae and Physciaceae species were present at all altitudes, and the dominant species changed according to altitude: Some Parmeliaceae species were found only at higher altitudes $(601-1430 \mathrm{~m})$ while Chrysothrix xanthina and a few Physciaceae species were present only at lower altitudes $(0-600 \mathrm{~m})$. These findings will provide additional information about the lichens of the tropical montane forest of Malaysia to enhance knowledge on how to manage and sustain lichens in this type of forest.

Keywords: Biodiversity; epiphytic lichen; montane forest; tropical lichen

\section{ABSTRAK}

Kajian ini dijalankan untuk melihat bagaimana kepelbagaian komposisi dan taburan spesies liken berbeza terhadap altitud dan faktor persekitaran (suhu dan kelembapan relatif). Kajian ini dijalankan di kawasan hutan Gunung Bunga Buah, Selangor di lima tapak kajian (berlainan altitud). Sebanyak 44 spesies liken telah dikenal pasti. Kepelbagaian, komposisi dan taburan spesies liken mempunyai korelasi terhadap altitud dan faktor persekitaran, peningkatan kepelbagaian berlaku dengan pertambahan ketinggian altitud. Liken daripada famili Graphidaceae dan Physciaceae wujud di setiap altitud dan jenis liken yang mendominasi adalah berbeza: spesies liken Parmeliaceae hanya dijumpai di altitud yang tinggi (601-1430 m) manakala Chrysothrix xanthina dan beberapa liken daripada famili Physciaceae hanya dijumpai di kawasan beraltitud rendah $(0-600 \mathrm{~m})$. Kajian ini memberikan informasi tambahan tentang kajian liken di hutan pergunungan tropika di Malaysia di samping mengembangkan ilmu untuk mengurus dan melestarikan liken di hutan pergunungan tropika.

Kata kunci: Hutan pergunungan; kepelbagaian biologi; liken epifit; liken tropika

\section{INTRODUCTION}

Lichen diversity and species composition are varied, depending on environmental conditions and type of ecosystems (Nimis et al. 2002). Lichens can be found growing from low-tide level to mountain summits, and from arctic and desert to tropical climate areas (Abas et al. 2018; Nash 2008). Lichens are unique dual-organisms (comprising fungus as mycobiont, and blue-green algae or cyanobacteria as photobiont) which can show immediate responses to changes in environmental conditions (Abas et al. 2020). Some species are able to grow under harsh environmental conditions, while even slight changes in their environment cause others to perish. Lichens have three different growth forms: Crustose, which grow attached to the substratum; foliose, which are leaf-like and loosely attached to the substratum; and fruticose, which are bushlike, and either hang, or grow upright on the substratum (Gaurav \& Upreti 2016). As well as their ecological roles, lichens with their metabolites have numerous biological properties, including antimicrobial, antiprotozoal, antiviral, 
anti-proliferative, anti-inflammatory, analgesic, antipyretic, anti-termite, antioxidant, cytotoxic, enzyme inhibitory, insecticidal, wound healing and antitumor properties (Kosanić et al. 2013; Rajan et al. 2016; Yilmaz et al. 2004). Malaysia, a tropical country, is known for its diverse and unique species of flora and fauna, but the study of lichens in Malaysia is far from complete (Abas \& Wang 2017). Most tropical lichens grow abundantly only at higher altitudes, such as in the montane forest, on hill summits, and in mountain ranges (Chongbang et al. 2018). The first lichen samples in Malaysia were recorded by Beccari (1904), who carried out a study on lichen in Sarawak. Galloway et al. (1994) prepared a bibliography of Malaysian lichenology comprising 90 entries, and Galloway et al. (1997) produced an additional list comprising a further 192 entries. Seven lichen genera collected from Bario, Sarawak were identified by Din et al. (1998). Zakaria et al. (2010) reported on the morphology and chemical constituents of Cladia aggregata collected from Gunung Jerai, Kedah. The chemical components of a few specific samples of Heterodermia flabellata and H. leucomela from Gunung Jerai, Kedah and the Cameron Highlands, Pahang were described by Din et al. (2010). Lichens of north eastern Langkawi and Gunung Machincang, Kedah were investigated by Zulkifly and Merican (2005), and lichen diversity and species composition ( 36 species were found) at Gunung Machincang were studied by Zulkifly et al. (2011). Urban lichen diversity and distribution in Kuala Lumpur were studied by Abas and Awang (2017), and those in Kota Kinabalu were studied by Abas et al. (2020). Abas et al. (2019a) reported 12 lichen species in Teluk Nipah, Pulau Pangkor, Perak.

Studies carried out in tropical forests have shown that environmental factors (e.g. temperature and humidity) and the forest structure will vary significantly with altitude (Boonpeng et al. 2017). Other research has shown that lichen diversity, composition, and distribution correlate significantly with, and are influenced by, environmental factors and the forest structure (Abas et al. 2019b; Sulaiman et al. 2018). Altitude has a strong connection with, and significant effects on, lichen diversity, composition, and distribution. The results of the present study are consistent with the findings of Abas et al. (2019a, 2019b), Upadhyay et al. (2018), and Zulkifly et al. (2011), who all concluded that lichen diversity, composition, and distribution increase significantly, the higher the forest altitude.

In Malaysia, there has been limited study of the lichens of tropical montane forest, and few studies are similar to our own. In this respect, Zulkifly et al. (2011) on Gunung Machincang, Langkawi, and Shahpuan et al. (2019) on foliicolous lichen in the rainforest of Sabah, stand out. However, the composition and distribution study of Shahpuan et al. (2019) was very basic. Abas et al. (2019a, 2019b) and Abas and Awang (2017) focused solely on lichen diversity in the lowland area, and more specifically on how lichen diversity was affected by air pollution and urbanization.

Information on lichen diversity, composition and distribution is still lacking for montane forests, especially in Malaysia. In addition, the uncontrolled development of land and recreational activity have affected the diversity of the fauna of Gunung Bunga Buah, Selangor. Hence, this study aims to identify and analyse lichen diversity, composition and distribution in Gunung Bunga Buah. It also aims to investigate the spatial distribution of lichens with regard to different elevations of Gunung Bunga Buah. It could also raise awareness of how environmental changes at Gunung Bunga Buah have affected the diversity of the mountain's flora and fauna.

\section{MATERIALS AND METHODS}

\section{STUDY AREA}

Gunung Bunga Buah is located at the border of SelangorPahang. Rising to $1430 \mathrm{~m}$, Gunung Bunga Buah is one the highest mountains in the state of Selangor, and part of its peak lies in the Titiwangsa Main Range of Peninsular Malaysia. The peak also borders on Pahang state and is close to the Pahang-Selangor border point. Gunung Bunga Buah is covered by an extensive montane forest, making it an attractive tourist destination for hiking and mountain climbing. There are three hiking routes to the peak, all of them built by the Malaysian Department of Wildlife and National Parks. In 1990, Gunung Bunga Buah's lowest recorded temperature was $14{ }^{\circ} \mathrm{C}$, but in 2015 it had increased to $18^{\circ} \mathrm{C}$. This temperature increase is due also to the development since 1995 of the nearby Genting Highlands and the numerous recreational activities conducted in the region since 1997, with the opening of its famous trail (Forest Department Peninsular Malaysia 2019).

The study was conducted at five sites along the hiking trail of Gunung Bunga Buah between the main entrance and Gunung Bunga Buah's peak (Figure 1). According to Zulkifly et al. (2011), the ecological stands of tropical forests vary every $200-400 \mathrm{~m}$. In order to observe change in lichen diversity, distribution and composition 
along elevational gradients, this study used mostly $300 \mathrm{~m}$ interval in selecting the study sites: Site 1 (0-300 m a.s.1.), Site 2 (300-599 m a.s.1.), Site 3 (600-999 m a.s.1.), Site 4 (1000-1299 m a.s.1.), and Site 5 (1300-1430 m a.s.1.). The study area has a warm tropical climate, with annual average minimum and maximum temperatures of 19 and $33{ }^{\circ} \mathrm{C}$ respectively, with the monthly rainfall can be as low as zero in January and as high as $342 \mathrm{~mm}$ in December, when there is heavy monsoon rain starting in November (Malaysian Meteorological Service 2018). The study sites included protected tropical rainforest reserves, and diverse species and a variety of forest structures are distributed throughout the region. In addition, Gunung Bunga Buah is also a protected area (Category VI: Protected Area with sustainable use of natural resources) under the management of Selangor State Forestry Department.

\section{SAMPLING PROCEDURES AND DATA ANALYSIS}

The sampling of lichens was carried out at five sites along the trail leading to the summit of Gunung Bunga Buah. The environmental conditions of the study sites (temperature, humidity, and altitude) were recorded (Table 1). The sampling plot at each site was determined using a stratified random sampling method for an area of $20 \times$ $20 \mathrm{~m}\left(400 \mathrm{~m}^{2}\right)$, the size being based on a preliminary site investigation, as recommended by Khaien et al. (2018). Only epiphytic lichens were collected. The coordinates of the lichens were noted.

The lichen samples were taken to the Algae Lab at the Universiti Kebangsaan Malaysia (UKM) for identification by observing their morphological traits under stereoscopic and optical microscopes. The external characteristics of the lichens (the lobes, thallus, pycnidia, rhizines, ciliates, and apothecia) were analysed thoroughly (Nimis et al. 2002). A spot test was used to determine the presence of acid (the lichen secondary metabolites) in the medulla and cortex (Sipman 2009). All the data acquired from both techniques (morphological observation and spot test) were recorded and incorporated into the Lichen Herbarium of UKM, Malaysia.

Lichen species richness and composition were calculated and presented as percentages of the total number of samples, using a cluster bar chart. An independent t-test was used to examine the difference in species composition between lower- and higher-frequency species (Sevgi et al. 2019). Species diversity was analysed using the two most common diversity indices - the ShannonWeiner index and Simpson's Diversity index. The Shannon-Weiner index is more useful in identifying rare species while Simpson's Diversity index is more useful and effective for more abundant species (Barnes et al. 1998; Simpson 1949). The Similarity index was used to investigate which lichens were endemic to certain sites (according to altitudinal difference). Correspondence Analysis (CA) was used to illustrate the variation in the species distribution and abundance along the elevational gradient in Gunung Bunga Buah (Benzecri 1973). All the statistical analyses were performed using the $\mathrm{R}$ program version 4.0, and SPSS statistical software version 23.0.

TABLE 1. The environmental conditions in each sampling site

\begin{tabular}{ccccc}
\hline Site & Coordinate & $\begin{array}{c}\text { Altitude } \\
(\mathrm{m})\end{array}$ & Relative humidity $(\%)$ & Temperature $\left({ }^{\circ} \mathrm{C}\right)$ \\
\hline 1 & $3.394046 \mathrm{~N}, 101.765730 \mathrm{E}$ & $0-299$ & 80.7 & 32.5 \\
2 & $3.383076 \mathrm{~N}, 101.765472 \mathrm{E}$ & $300-599$ & 81.1 & 31.8 \\
3 & $3.370838 \mathrm{~N}, 101.751314 \mathrm{E}$ & $600-899$ & 82.5 & 27.1 \\
4 & $3.374701 \mathrm{~N}, 101.745414 \mathrm{E}$ & $900-1199$ & 87.9 & 23.2 \\
\hline
\end{tabular}

Source: Malaysia Meteorological Department (2019) 


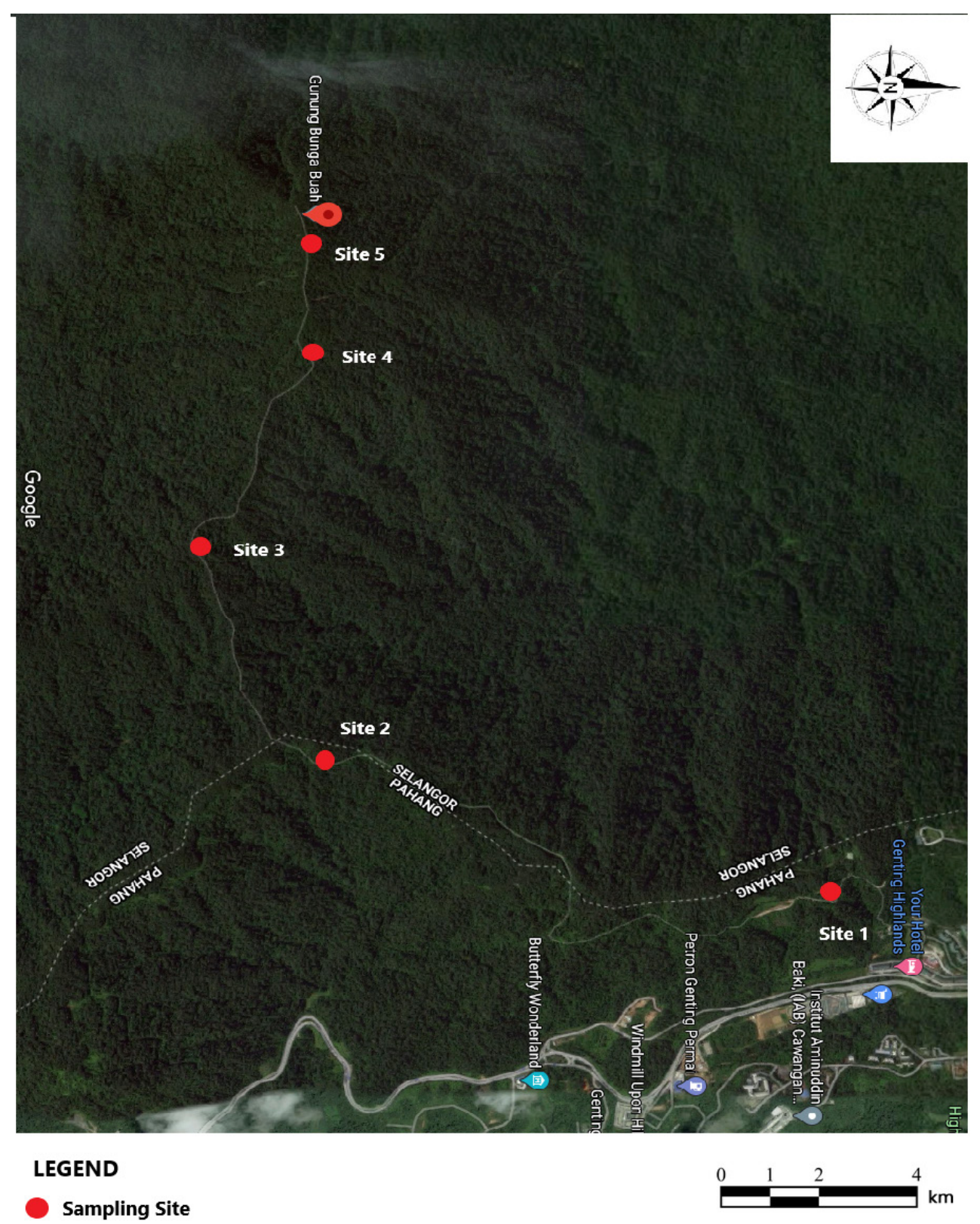

FIGURE 1. Sampling sites at Gunung Bunga Buah, Selangor

\section{RESULTS}

LICHEN SPECIES DIVERSITY

A total of 44 lichen species belonging to 11 families were collected from Gunung Bunga Buah. The highest number of species collected was at Site 5 (35 species), followed by Site 4 (32), Site 3 (31), Site 2 (25), and lastly Site 1
(21). The diversity of lichen species for each site was determined using the Shannon-Weiner index (Figure 2) and Simpson's Diversity index (Figure 3). The diversity varied significantly among sampling sites (ANOVA, $p<0.05$ ), with Site 5 having the greatest diversity, showing that lichen species diversity tends to increase with increased altitude. 


\section{LICHEN SPECIES COMPOSITION AND DISTRIBUTION}

The lichen species composition and distribution varied within and among the sampling sites. Bar charts were produced to analyse lichen distribution and composition for each of the sampling sites (Figure 4). Lichen species from families Graphidaceae, Physiaceae, Pyrenulaceae, and Chryptotaceae were found at all the sampling sites, but the particular species found varied from one site to another site. Some species were found at only one site - for example, Chrysothrix xanthina at Site 1, and Parmotrema mellissii and Parmelia sulcata at Site 5.

As shown in Figure 4(a), two dominant species were found at Site 1, namely Graphis librata and Pyrenula ochraceoflava (both $12.7 \%$ of the samples). This was followed by Dirinaria applanata (10.5\%), Dirinaria picta (9.0\%), Chrysothrix xanthina (7.7\%), Graphis casiella (6.6\%), Graphis hiascens (6.6\%), Dirinaria aegialita (5.0\%), and Pyxine berteriana $(5.0 \%)$. The remaining species had percentages below 5\% - Phaegraphis caesioradians (1.1\%), Rinodina oxydata (1.1\%), and Ocellularia papilillata $(0.5 \%)$. The majority of the samples from Site 1 were from the crustose group, and only $C$. xanthina was from the leprose group. Graphidaceae and Physciacea were the dominant lichen families for Site 1, and both the families were represented by at least five species.

At Site 2, the most dominant species was again Graphis librata, with $12.4 \%$ of the samples (Figure 4(b)). This was followed by Dirinaria picta $(11.44 \%)$, Graphis scripta (10.44\%), Graphis furcata (7.0\%), Graphis hiascens (6.97\%), Pyrenula ochraceoflava (6.97\%), Dirinaria applanata (6.47\%), Graphis caesiella (5.0\%), and Graphis glaucescens $(5.0 \%)$. The lowest figures for Site 2 were Phaeographis leioplacella $(0.5 \%)$ and Pyrenula petivica $(0.99 \%)$. The majority of the species collected at the site were from the crustose lichen group. Graphidaceae and Physciaceae were again the most dominant families at Site 2, represented by at least five species each.

Figure 4(c) shows the composition distribution of lichen species for Site 3. The most dominant species was Graphis caesiella, with $10.19 \%$ of the samples, and this was followed by Dirinaria picta $(8.8 \%)$, Graphis furcata (7.41\%), Trypethelium tropicum (6.02\%), Cryptothesia granularis $(6.02 \%)$, Graphis librata $(5.56 \%)$, and Pramotrema praesorediosum (5.56\%). Coccocarpia erythroxyli and Cryptothesia striata were among the lichen species that scored less than 5\%. The majority of the lichens found at Site 3 belonged to the crustose group, but foliose lichens such as Coccocarpia erythroxyli and Pramotrema praesorediosum were also collected at this site. The most dominant family was Graphidaceae (12 species), and two species of Parmeliaceae and one species of Coccocarpiaceae were also found at Site 3.

Site 4 recorded 32 lichen species (Figure 4(d)). The most dominant species here was Graphis caesiella (7.81\%), followed by Graphis librata (7.58\%), Trypethelium epileucodes (7.19\%), Lepraria usnica (6.47\%), Graphis scripta (6.12\%), and Trypethelium tropicum (5.4\%). Coccocarpia erythroxyli and Parmotrema tinctorum both accounted for less than $5 \%$ of samples. Crustose lichens dominated, but the foliose group was also represented by several species. Graphidaceae was the dominant lichen family at Site 4; other species belonged to the Collemataceae family.

Figure 4(e) shows the lichen species composition and distribution for Site 5. The most dominant species was Parmotrema praesorediosum (8.59\%), followed by Trypethelium epileucodes (7.42\%), Trypethelium eluteriae (6.64\%), Graphis caesiella (6.25\%), Coccocarpia pellita, and Lepraria usnica (5.08\%). Bulbothrix isidiza and Parmotrema mellissii each accounted for less than 5\% of the samples. Both crustose and foliose lichen groups were found abundantly. Graphidaceae was the dominant lichen family, but Parmeliaceae was also well represented.

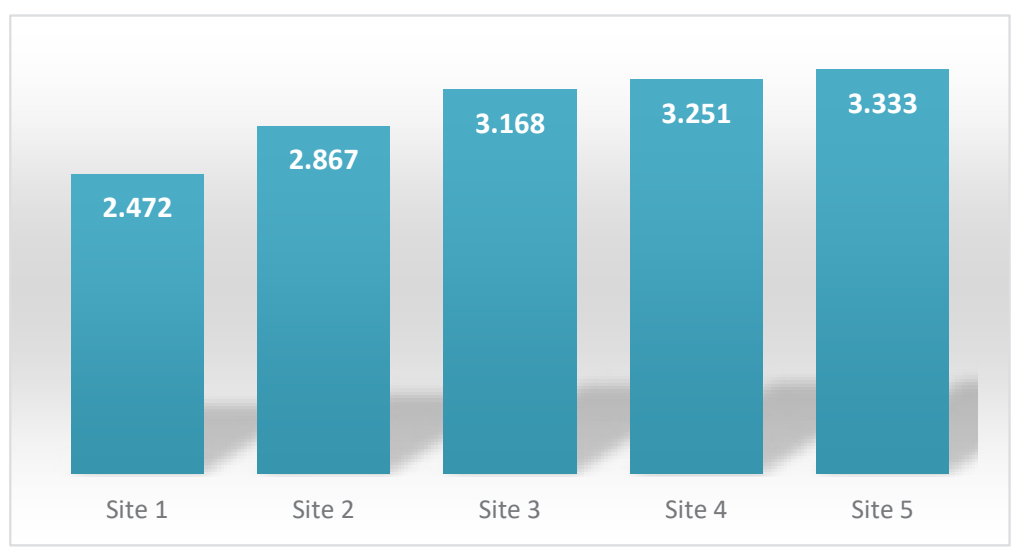

FIGURE 2. The Shannon-Weiner index for the five sampling sites 


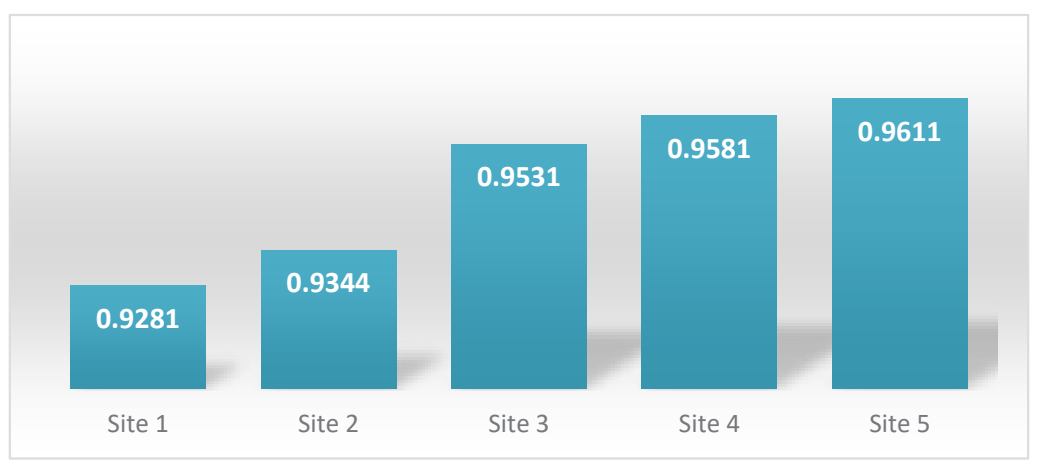

FIGURE 3. Simpson's Diversity index for the five sampling sites

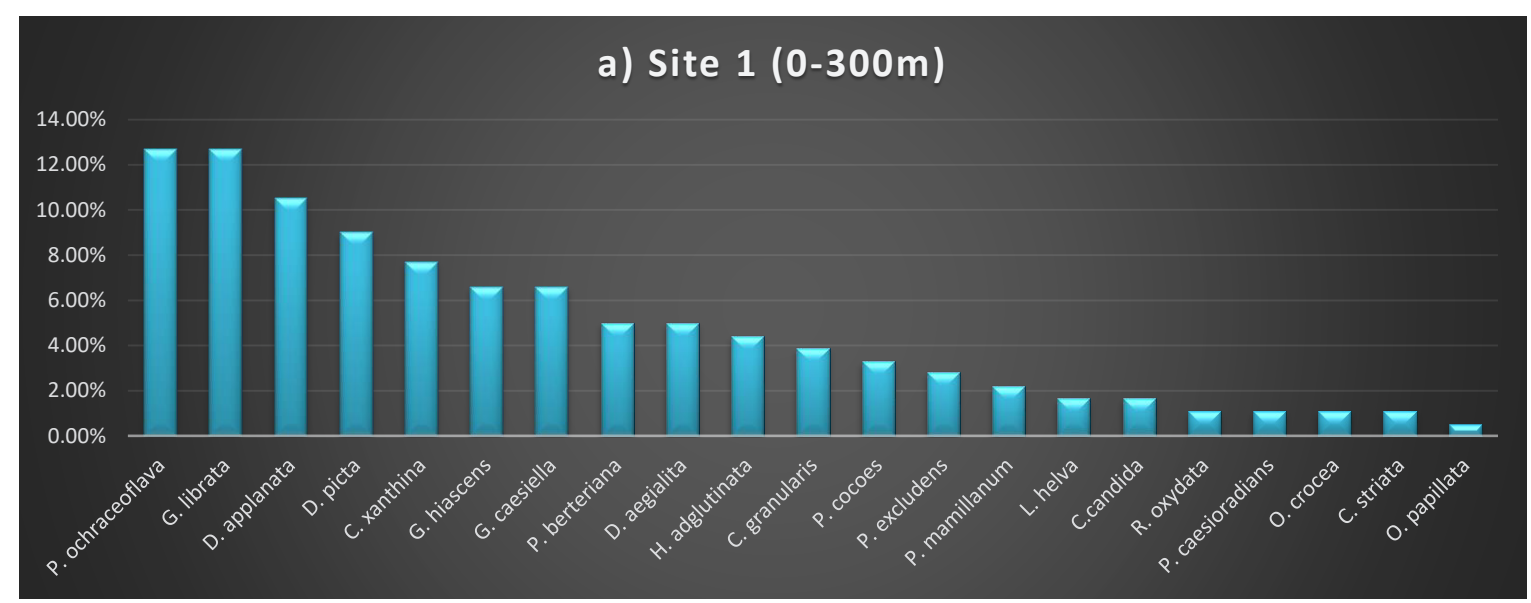

b) Site $2(301-600 \mathrm{~m})$

$14.00 \%$

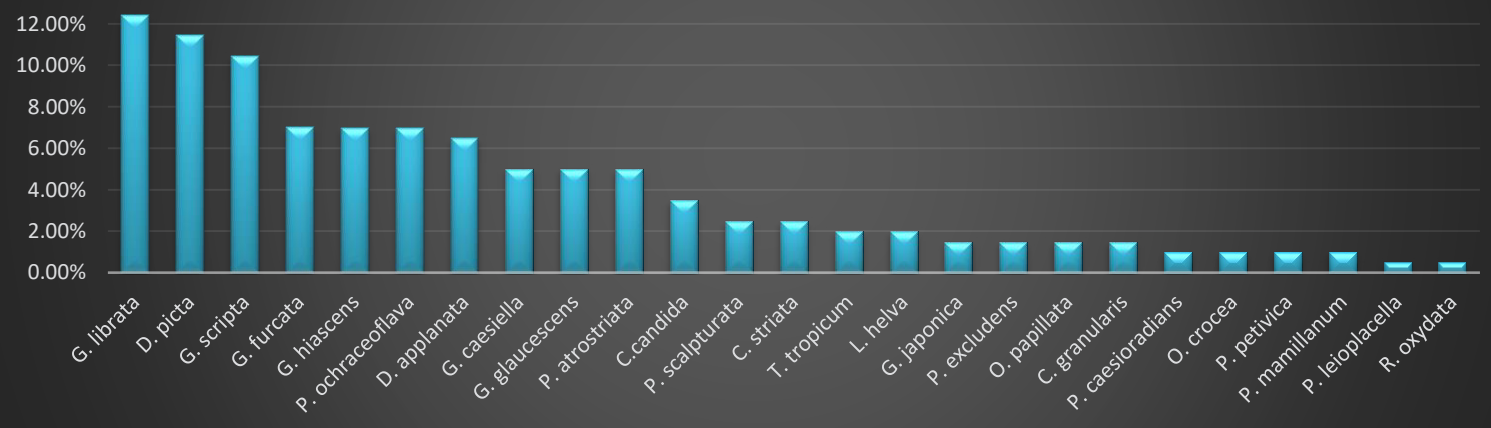

c) Site $3(601-900 \mathrm{~m})$

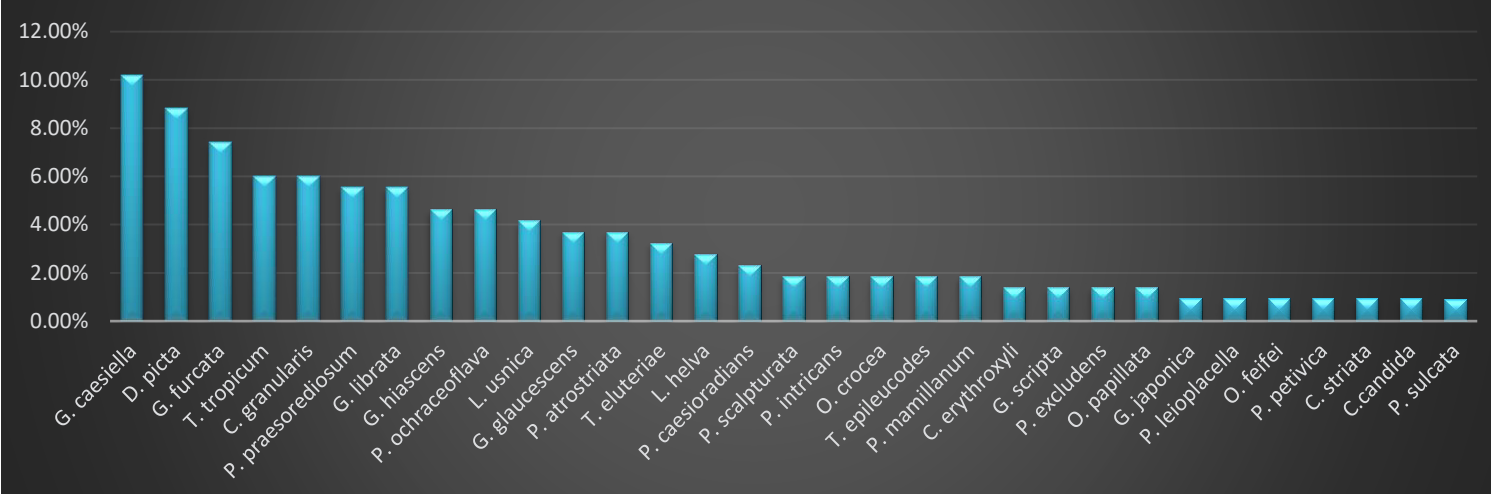



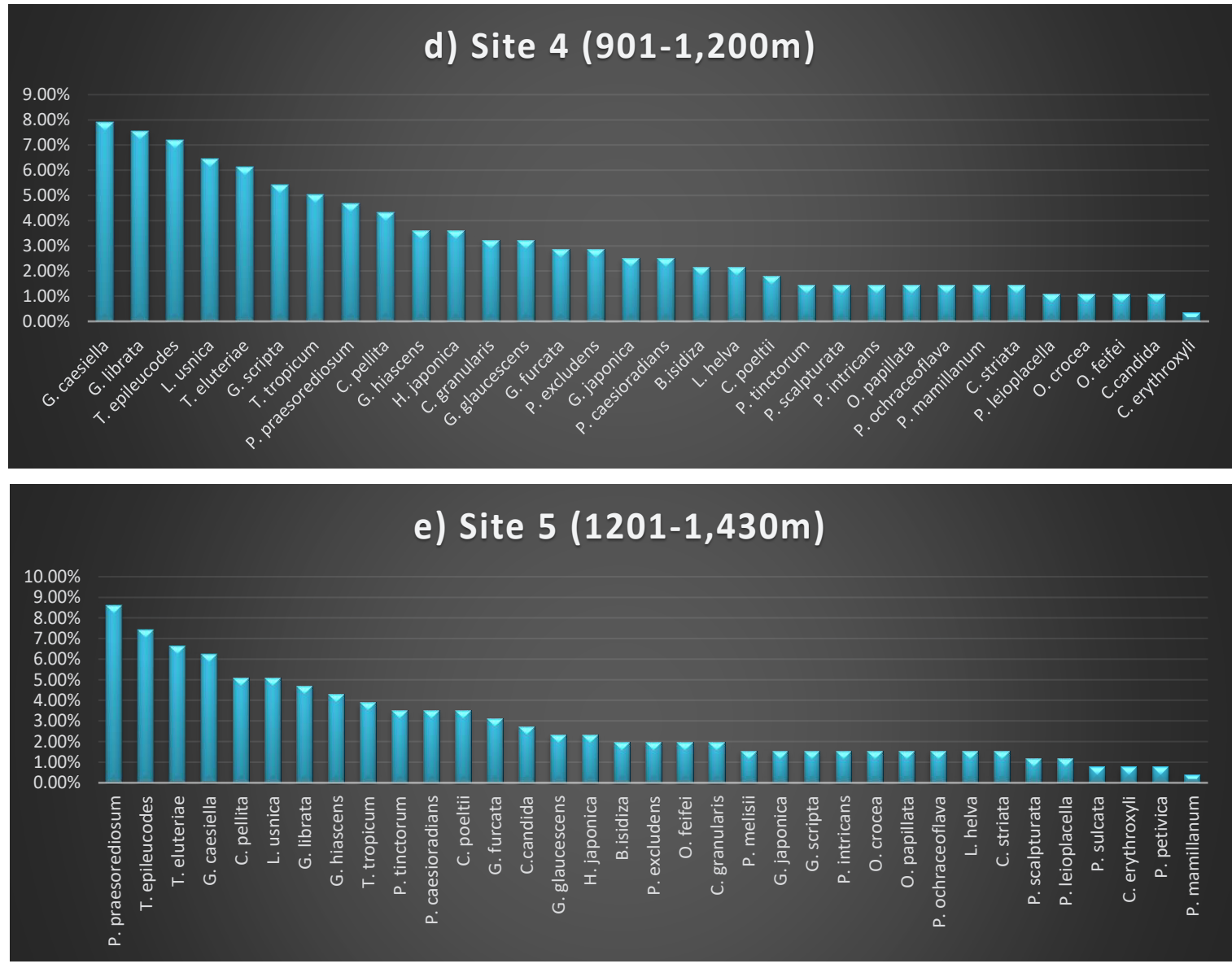

FIGURE 4. Distribution of lichen species for each sampling site (a) Site 1, (b) Site 2, (c) Site 3, (d) Site 4, and (e) Site 5

THE SIMILARITY INDEX FOR THE SAMPLING SITES The similarity index showed how the sites differed according to the presence or absence and abundance of species (Table 2). The similarity between Sites 4 and 5 was higher than for Sites 3 and 4, or for Sites 3 and 5. Sites 1 and 5 had the lowest similarity (less than 30\%).
The sampling sites can be classified into two main groups based on their ecological distances. The dendrogram showed that the ecological distances between Sites 3 and 5, and between Sites 1 and 2 were the closest (Figure 5). Thus, altitudes of 601-1493 $\mathrm{m}$ can be considered as one group, with altitudes of 0-600 $\mathrm{m}$ falling into a separate group.

TABLE 2. The similarity index data in each sampling site

\begin{tabular}{lccccc}
\hline & Site 1 & Site 2 & Site 3 & Site 4 & Site 5 \\
\hline Site 1 & & 0.570681 & 0.433249 & 0.331155 & 0.28833 \\
Site 2 & & & & \\
Site 3 & 0.570681 & & 0.623501 & 0.480167 & 0.424508 \\
Site 4 & 0.433249 & 0.623501 & & 0.663968 & 0.631356 \\
Site 5 & 0.331155 & 0.480167 & 0.663968 & & 0.816479 \\
\hline
\end{tabular}




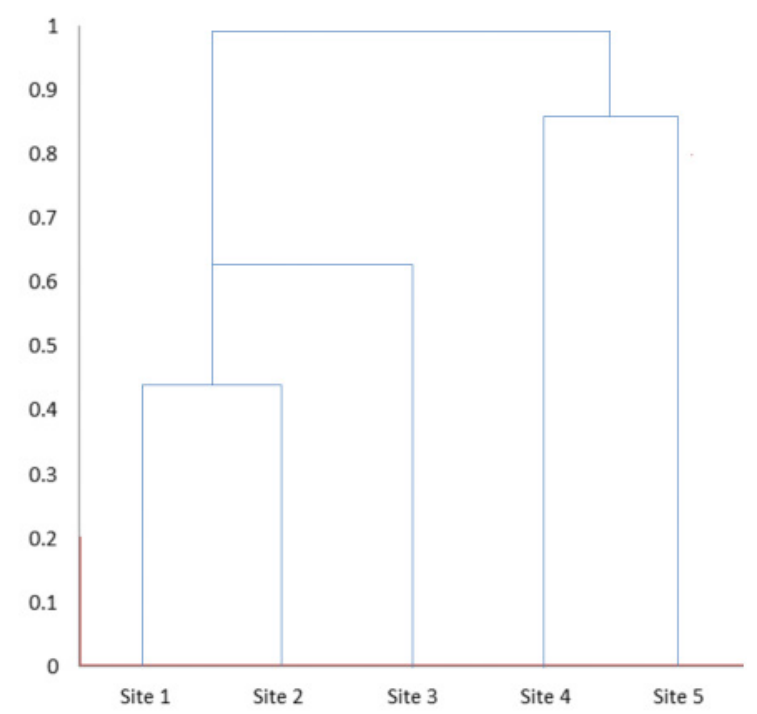

FIGURE 5. The dendrogram showing the similarity of abundance of species in each site

\section{EFFECTS OF ALTITUDE ON LICHEN SPECIES DIVERSITY,} COMPOSITION AND DISTRIBUTION

Lichen diversity, composition, and distribution varied according to altitude, and environmental conditions (humidity and temperature). The differences between lichen diversity and abundance correlated significantly with the location altitude, temperature, and humidity. Altitude and environmental factors had a stronger effect on species distribution from 0 to $1493 \mathrm{~m}$. CA showed that there was a very clear correlation between species diversity and distribution on one hand, and sampling site altitude on the other (Figure 6). The first and second axes of CA showed more than $60 \%$ of the total fitted variation. The weighted average scores for lichen diversity at different altitudes varied greatly, with the abundance and distribution of lichens spreading into different quarters of the ordination graph. Where a sampling point in the graph is located close to a particular species, that species is expected to be highly abundant and frequent at the sampling point. Chrysothrix xanthina, $P$. cocoes, $P$. berteriana, $H$. adglutinata, and D. aegialita were located close to Site 1, meaning that these species were abundant only at Site 1, indicating that a higher altitude than that of Site 1 was not an appropriate condition and habitat for this species. It should be noted that a small vector angle between species corresponds to a strongly positive association, and a $180^{\circ}$ vector angle between species corresponds to a negative correlation.

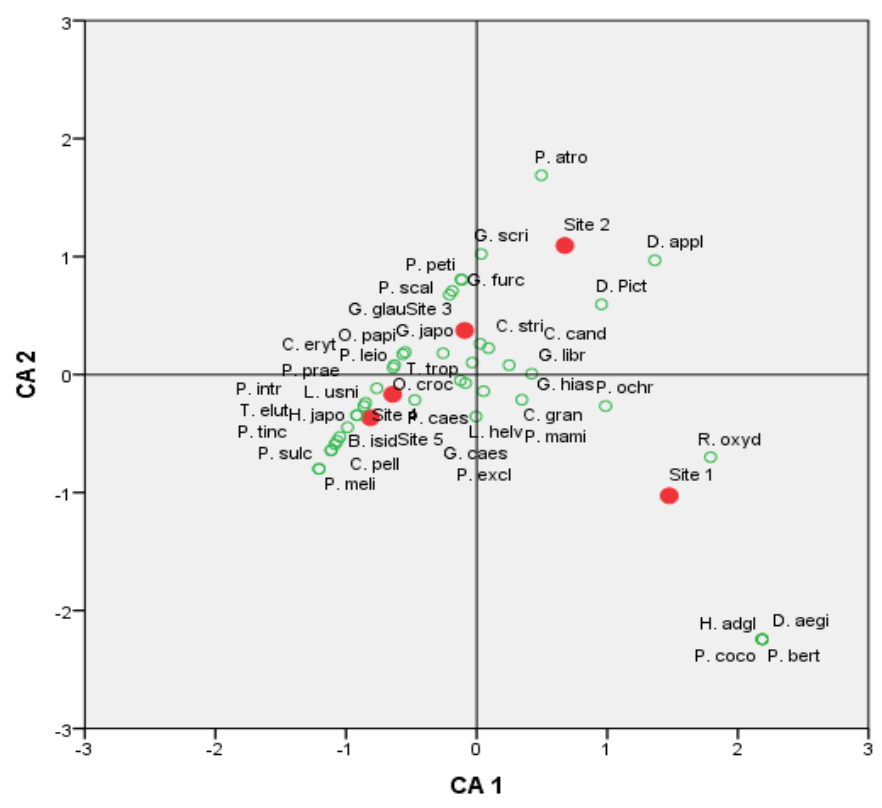

FIGURE 6. The relationship of species distribution at different sampling sites based on correspondence analysis 


\section{DISCUSSION}

Lichen species that belong to the Graphidaceae and Physciaceae families were present at all forest altitudes (Sites 1-5), but the specific species that emerged were different. For example, among the species of Graphidaceae, Phaeographis intricans and Graphis japonica were present only at 601-1493 m (Sites 3-5), while Heterodermia japonica, of the Physciaceae family, was found only at 901-1493 m (Sites 4 and 5). On the other hand, Dirinaria aegialita, Pyxine cocoes, Pyxine berteriana, and Hyperphyscia adglutinata (all Physciaceae) were present at 0-300 m only (Site 1). Similarly, Chrysothrix xanthina (a leprose lichen) was found only at 0-300 $\mathrm{m}$. These differences can be explained by the differing environmental factors between altitudes. For example, altitudes $0-300 \mathrm{~m}$ is a lowland area, which is vulnerable to air pollution and human activities. Anthropogenic activities lead to increased nitrogen and sulphur in the atmosphere, and only acidophile and nitrophile types of lichens can survive in high concentrations of these elements. Parmeliaceae, Coccocarpiaceae and Collemataceae species were present only at high altitudes (601-1493 m; Sites 3-5). These three families are foliosetype lichens, which only grow at low temperatures in areas of high humidity. A study by Sipman (2009) concluded that foliose-type lichens can grow abundantly at higher altitudes in regions with tropical climates. In addition, most of the Parmeliaceae, such as Parmotrema tinctorum, Parmotrema mellissii, and Coccocarpia pellita, are highly sensitive to air pollution, and they are commonly found only in pristine and remote forests.

Species distribution correlated strongly with climatic conditions, especially temperature and relative humidity. Furthermore, the abundance of species has been proved to vary according to altitudinal zone. Our study found that Chrysothrix xanthina, Pyxine cocoes, Pyxine berteriana, Dirinaria aegialita, Rinodina oxydata, and Hyperphyscia adglutinata grew exclusively at altitudes of 0-300 m, with average coverage of 33\%. Dirinaria picta, Dirinaria applanate, and Physcia atrostriata grew in abundance at 301-600 m, where they were $55 \%$ more abundant than at lower altitudes. Graphis japonica and Cryptothesia striata were found exclusively at $601-900 \mathrm{~m}$, with average coverage of $44 \%$ for both species. Several Parmeliaceae, Coccocarpiacea, and Collemataceae species, such as Parmotrema tinctorum, Parmotrema praesorediosum, Parmotrema mellissii, Bulbothrix isidiza, Parmelia sulcata, Coccocarpia pellita, Coccocarpia erythroxyli, and Collema poeltii, were found thriving at $901 \mathrm{~m}$ and above, with average coverage of $53 \%$.
Our study found that some lichen species, such as Cryptothesia granularis, Ocellularia crocea, Graphis librata, and Graphis caesiella, were present at almost all altitudes. This is in agreement with the findings of Zulkifly et al. (2011), who found that some Graphidaceae and Cryptothesiacea species were common in montane forest at all altitudes. This may be due to the ability of this lichen family to adapt, making it less vulnerable to its surroundings even if there are changes in the quality of the environment (Abas et al. 2018).

Geographically, tropical forests are located in equatorial regions (Khamis \& Nizam 2013). This gives the forests a unique structure which makes them suitable habitats for thousands of endemic bryophyte and lichen species (Sevgi et al. 2019). The number of lichen species found in Gunung Bunga Buah, Selangor (44 species) was significantly higher than that found for the montane forest at Gunung Machincang, Langkawi (33 species) (Zulkifly et al. 2011). Somewhat fewer lichen species again were found in Araucaria forest of Southern Brazil (27 species) (Kaffer et al. 2009). The varying numbers of lichen species present in different areas may be due to physical geographical boundaries and climatic variation.

\section{CONCLUSION}

In this study, we found that lichen species diversity, composition and distribution in Gunung Bunga Buah, Selangor increased with the montane forest altitude. The dominant lichen species also varied according to altitude. Although the diversity did not change significantly between 0 and $600 \mathrm{~m}$ (Sites 1 and 2), it did do so at altitudes 601$1430 \mathrm{~m}$ (Sites 3-5) with the presence of a few endangered lichen species. Given the link between altitudinal gradient and environmental factors (lower temperature and higher humidity at higher altitudes) which are essential for lichen growth and forest productivity, our findings are consistent with earlier studies that show a positive correlation between lichen species and forest altitude. The study also verified that some lichen species present in Gunung Bunga Buah that may be threatened by the loss of forest and human activities, such as Parmotrema mellissii, Collema poeltti, and Coccocarpia pellita. These species need to be protected and managed to ensure their survival in this tropical montane forest. Our findings add to knowledge of Malaysian lichens, and have implications for phytogeography and ecology, especially montane forest ecology, giving insight into how elevation gradient and variation of environmental factors can determine the diversity, composition and distribution of lichens. The results of our study will thus be of use in determining appropriate management techniques in tropical regions more widely. 


\section{ACKNOWLEDGEMENTS}

This study was conducted with the financial support of GUP-2018-032 research grant provided by Universiti Kebangsaan Malaysia. We are grateful to everyone who helped with the field survey. We would like to thank all anonymous reviewers for their constructive comments. Also, we want to thank Dr. Rose Norman (Read by Rose) for her help in proofreading this article.

\section{REFERENCES}

Abas, A. \& Awang, A. 2017. Air pollution assessment using lichen biodiversity index (LBI) in Kuala Lumpur, Malaysia. Pollution Research 36(2): 242-249.

Abas, A., Awang, A. \& Aiyub, K. 2020. Analysis of heavy metal concentration using transplanted lichen Usnea misaminensis at Kota Kinabalu, Sabah (Malaysia). Applied Ecology and Environmental Research 18(1): 1175-1182.

Abas, A., Khalid, R.M., Rosandy, A.R. \& Sulaiman, N. 2019a. Lichens of Pulau Pangkor, Perak. The Malaysian Forester 82(1): 59-66.

Abas, A., Sulaiman, N., Adnan, N.R., Aziz, S.A. \& Nawang, W.N.S.W. 2019b. Using lichen (Dirinaria sp.) as bioindicator for airborne heavy metal at selected industrial areas in Malaysia. Environment Asia 12(3): 85-90.

Abas, A., Awang, A. \& Din, L. 2018. Liken: Khazanah Hidupan Terasing. Bangi: Penerbit Universiti Kebangsaan Malaysia.

Barnes, B.V., Zak, D.R., Denton, S.R. \& Spurr, S.H. 1998. Forest Ecology. 4th ed. New York: John Wiley and Sons Inc. pp. 488-489.

Beccari, O. 1904. Wanderings in the Great Forest of Borneo. London: Constable \& Co.

Benzecri, J.P. 1973. L'analyse des Donnees. L'analyse des Correspondances. Paris: Dunod. p. 1190.

Boonpeng, C., Polyiam, W., Sriviboon, C., Sangiamdee, D., Watthana, S., Nimis, P.L. \& Boonpragob, K. 2017. Airborne trace elements near petrochemical industry complex in Thailand assessed by the lichen Parmotrema tinctorum (despr. Ex Nyl.) Hale. Environmental Science and Pollution Research 24(13): 1-8.

Chongbang, T.B., Keller, C., Nobis, M., Scheidegger, C. \& Baniya, C.B. 2018. From natural forest to cultivated land: Lichen species diversity along land-use gradients in Kanchenjunga, Eastern Nepal. Journal on Protected Mountain Areas Research 10(1): 46-60. doi:10.1553/eco. mont-10-1s46.

Din, L.B., Zakaria, Z., Samsudin, M.W. \& Elix, J.A. 2010. Chemical profile of compounds from lichens of Bukit Larut Peninsular Malaysia. Sains Malaysiana 39(6): 901908.

Forestry Department Peninsular Malaysia. 2019. Gunung Bunga Buah, Selangor. 15th September 2019. https://www. forestry.gov.my/my/selangor/hutan-lipur-gunung-bungabuah.
Galloway, D.J., Din, L.B. \& Latiff, A. 1997. A bibliography of Malaysian lichenology. Malaysian Applied Biology 26(1): 93-99.

Galloway, D.J., Samsudin, M.W. \& Latiff, A. 1994. A bibliography of Malaysian lichenology. Malaysian Applied Biology 22: 215-221.

Gaurav, K.M. \& Upreti, D.K. 2016. Diversity and distribution of macro-lichen in Kumaun Himalaya, Uttarakhand. International Journal Advance Research 4(2): 912-925.

Kaffer, M.I., Ganade, G. \& Marcelli, M.P. 2009. Lichen diversity and composition in Araucaria forests and tree in Southern Brazil. Biodiversity Conservation 18: 3543-3561.

Khamis, S. \& Nizam, M.S. 2013. Distribution of Litsea complex (Lauraceae) and their association with soil properties in different forest types of Peninsular Malaysia. AIP Conference Proceedings.

Kosanic, M., Rankovic, B. \& Stanojkovic, T. 2013. Investigation of selected Serbian lichens for antioxidant, antimicrobial and anticancer properties. The Journal of Animal \& Plant Sciences 23(6): 1628-1633.

Nash, T.H. 2008. Lichen Biology. 4th ed. Cambridge: Cambridge University Press.

Nimis, P.L., Scheidegger, C. \& Wolseley, P.A. 2002. Monitoring with Lichens. Netherland: Springer.

Rajan, V.P., Gunasekaran, S., Ramanathan, S., Murugaiyah, V., Samsudin, M. \& Din, L. 2016. Biological activities of four Parmotrema species of Malaysian origin and their chemical constituents. Journal of Applied Pharmaceutical Science 6(8): 36-43

Sevgi, E., Yılmaz, O.Y., Çobanoğlu Özyiğitoğlu, G., Tecimen, H.B. \& Sevgi, O. 2019. Factors influencing epiphytic lichen species distribution in a managed Mediterranean Pinus nigra Arnold Forest. Diversity 11(4): 59.

Shahpuan, M.S., Laneng, L.A., Looi, K.C., Inaguma, Y. \& Vairappan, C.S. 2019. New dataset of foliicolous lichens on leaves of five major species of Dipterocarpaceae in INIKEA forest rehabilitation plot of Borneo. Data in Brief 27: 104422 .

Simpson, E.H. 1949. Measurement of diversity. Nature 163: 688. Sipman, H. 2009. Tropical urban lichens: Observations from Singapore. Blumea 54: 297-299.

Sulaiman, N., Mohd Fuzy, S.F.F., Abdul Muis, S.I.N., Sulaiman, N. \& Ismail, B.S. 2018. Use of lichens as bioindicators for determining atmospheric heavy metals concentration in Malaysia. Pakistan Journal of Botany 50(1): 421-428.

Upadhyay, S., Jugran, A.K., Joshi, Y., Suyal, R. \& Rawal, R.S. 2018. Ecological variables influencing the diversity and distribution of macrolichens colonizing Quercus leucotrichophora in Uttarakhand forest. Journal of Mountain Science 15(2): 307-318. doi:10.1007/s11629-017-4397-9.

Yilmaz, M., Türk, A.Ö., Tay, T. \& Kıvanç, M. 2004. The antimicrobial activity of extracts of the lichen Cladonia foliacea and its (-)-usnic acid, atranorin and fumarprotocetraric acid constituents. Zeitschriftfür Naturforschung C 59(3-4): 249-254. 
Zulkifly, S. \& Merican, A.F. 2005. Some lichens of north eastern Langkawi and Gunung Machincang, Langkawi Islands. Malaysian Journal of Science 24: 103-110.

Zulkifli, S., Kim, Y.S., Abdul Majid, M. \& Merican, A.F. 2011. Distribution of lichen flora at different altitudes of Gunung Machincang, Langkawi Islands, Malaysia. Sains Malaysiana 40(11): 1201-1208.

Azlan Abas*

Centre for Research in Development

Social and Environment

Faculty of Social Sciences and Humanities

Universiti Kebangsaan Malaysia

43600 UKM Bangi, Selangor Darul Ehsan

Malaysia

\section{Laily Din}

Department of Chemical Sciences

Faculty of Science and Technology

Universiti Kebangsaan Malaysia

43600 UKM Bangi, Selangor Darul Ehsan

Malaysia

*Corresponding author; email: azlanabas@ukm.edu.my

Received: 25 March 2020

Accepted: 5 October 2020 